\title{
Analisis Postur Kerja dengan RULA Guna Penilaian Tingkat Risiko Upper Extremity Work-Related Musculoskeletal Disorders. Studi Kasus PT. Mandiri Jogja Internasional
}

\author{
Titin Isna Oesman ${ }^{1}$, Era Irawan ${ }^{2}$, Petrus Wisnubroto ${ }^{3}$ \\ Jurusan Teknik Industri Fakultas Teknologi Industri, Institut Sains \& Teknologi AKPRIND \\ Yogyakarta \\ erairawan13@gmail.com \\ doi: https://doi.org/10.24843/JEI.2019.v05.i01.p06
}

Article Received: 18 Maret 2019; Accepted: 20 Mei 2019; Published: 30 Juni 2019

\begin{abstract}
Abstrak
Industri kerajinan kulit memproduksi berbagai produk seperti tas, sepatu, dompet, ikat pinggang. Pada proses produksi di divisi pemotongan, kondisi postur kerja terlalu membungkuk. Studi pendahuluan pada 20 orang pekerja didapatkan keluhan musculoskeletal yang menyatakan sakit lebih besar dari $50 \%$ pada 16 item, sebagian besar pada anggota badan bagian atas. Berdasarkan keluhan tersebut dilakukan penelitian terhadap postur kerja dengan metode RULA dan Symtom Questionnaire. Tujuan penelitian untuk mengetahui tingkat risiko dan hubungan dengan UEWMSDs pada pekerja di PT Mandiri Jogja Internasional. Hasil penelitian dengan metode RULA diperoleh skor postur kerja sebesar 7 (tujuh) yang berarti tingkat risiko 3 (tiga) dan termasuk kategori sangat tinggi sehingga perlu dilakukan perbaikan secepat mungkin. Symtom Questionnaire menunjukkan sesuai dengan keluhan pekerja yaitu keluhan sakit bahu dan lengan (50\%), timbul rasa sakit setelah bekerja 1-4 tahun (85\%), lama sakit <1 jam (85\%), pindah ke bagian lain karena sakit (55\%), yang dapat menambah rasa sakit bila beraktivitas $(100 \%)$, yang dapat mengurangi rasa sakit bila istirahat $(90 \%)$. Berdasarkan kondisi tersebut maka diredesain meja potong yang dievaluasi RULA katagori 3 (tiga), dengan ukuran sesuai antropometri pekerja.
\end{abstract}

Kata kunci: postur kerja, RULA, keluhan musculoskeletal, UEWMSDs

\author{
Work Posture Analyze Using RULA for Risk Level Assessment of Upper Extremity \\ Work-Related Musculoskeletal Disorders. Case Study \\ at PT. Mandiri Jogja Internasional
}

\begin{abstract}
Leather handycraft industry produces handicrafts such as bags, shoes, wallets, belts. On production process atcutting division, work posture condition is too bent. A preliminary study on 20 workers found musculoskeletal complaints was greater than $50 \%$ at 16 items, mostly in upper limbs. Based on these complaints, research was on work posture using RULA and Sympton Questionnaire. Research purposes was to determine the risk level and relationship with UEWMSDs on the worker. The result of RULA found that work posture with RULA score was 7 (seven) that means 3 (three) risk level that very high category, and needs to be repaired as soon as possible. Symptom Questionnaire answer related to worker's complaint, which are complaints of shoulder and arm pain was $50 \%$, pain after work 1-4 years was $85 \%$, duration of illness $<1$ hour was $85 \%$, move to another part due to illness was $55 \%$, pain increase when the activity was $100 \%$, and pain reduce at rest was $90 \%$. Base on the condition, it was needed to redesigned cutting table evaluated by RULA category 3 (three) based on anthropometry of workers.
\end{abstract}


Keywords: work posture, RULA, musculoskeletal complaints, UEWMSDs

\section{PENDAHULUAN}

Industri kerajinan kulit banyak memperoduksi kerajinan seperti tas, sepatu, dompet maupun ikat pinggang. Salah satu industri kerajinan adalah PT. Mandiri Jogja Internasional Internasional. Pada proses produksi yaitu di divisi pemotongan, kondisi postur kerja terlalu membungkuk. Pekerja proses produksi kulit melakukan gerakan berulang-ulang atau repetitif terutama bagian ekstremitas atas sesuai tuntutan pekerjaan dan standar tempat kerja.

Suatu proses produksi merupakan suatu sistem kerja yang saling mendukung satu sama lain tiap-tiap bagian berhubungan. Sistem kerja yang belum ergonomis dalam satu perusahaan sering kali kurang mendapat perhatian dari pihak manajemen perusahaan. Pada kondisi sikap kerja divisi pemotongan PT. MJI dijumpai leher dan punggung terlalu membungkuk sehingga dapat menyebabkan risiko tinggi keluhan UEWMSDs bagi pekerja divisi pemotongan.

Pada studi pendahuluan dengan menyebar Nordic Body Map (NBM) kepada 20 pekerja divisi pemotongan, jawaban yang menyatakan sakit $\geq 50 \%$ terjadi pada 16 item sebagai yaitu sakit leher atas 65\%, sakit leher bawah 55\%, sakit bahu kiri $65 \%$, sakit bahu kanan $70 \%$, sakit lengan atas kanan 55\%, sakit pada pinggang 70\%, sakit lengan bawah kanan 50\%, sakit pergelangan lengan kiri 55\%, sakit tangan kanan 55\%, sakit lutut kiri 55\%, sakit lutut kanan $55 \%$, sakit betis kiri $60 \%$, sakit betis kanan 50\%, sakit pergelangan kaki kiri 50\%, sakit pergelangan kaki kanan 50\%, dan sakit pada kaki kiri 55\%. Hasil pengolahan data kuesioner $N B M$ studi pendahuluan diperoleh keluhan nyeri yang paling sering muncul adalah pada bagian leher dan pada bagian punggung dikarenakan posisi posisi bendiri yang tidak sesuai dengan ketinggian meja atau pemotongan pola, sehingga menyebabkan keluhan musculoskeletal.

Menurut Hartono (2004), pekerja melakukan gerakan tangan berulang untuk jangka waktu yang lama dan sering kali disertai beban yang berat. Berdasarkan penelitian ini didapatkan gejala $U E W M S D$ s sebesar $46 \%$. Kelainan UEWMSDs yang terbanyak adalah kumpulan gejala nyeri bahu yang timbul akibat adanya jepitan atau penekanan pada tendon. Faktor yang berhubungan dengan UEWMSDs adalah sikap dan posisi anggota tubuh pada waktu bekerja dengan skor RULA. Tujuannya untuk mengetahui faktor-faktor yang berhubungan dengan Upper Extremity Work-Related Musculoskeletal Disorders (UEWMSDs) melalui pengamatan secara subjektif dan objektif.

Menurut Dzikrillah dan Yuliani (2015), desain tempat kerja akan sangat bergantung pada jenis pekerjaan dan alat yang digunakan untuk menunjang pelaksanaan operasi kerja. Sementara kondisi kerja dapat didesain secara ergonomis dengan menyesuaikan pekerjaan dan alat serta manusia penggunanya. Ergonomi didefinisikan sebagai ilmu, seni, dan teknologi untuk menyerasikan alat, metode, dan lingkungan kerja terhadap kemampuan, kebolehan, dan keterbatasan manusia baik fisik maupun mental. Kondisi kerja dan lingkungan yang aman, nyaman, sehat, bugar dan efisien yang pada akhirnya produktivitas setinggi-tingginya yang diharapkan dapat tercapai dan kualitas hidup menjadi lebih baik (Manuaba, 1998).

Kondisi kerja yang tidak ergonomi akan menimbulkan keluhan muskuloskeletal. Sistem musculoskeletal terdiri atas tulang dan otot rangka yang bersifat otot sadar. Fungsi utama sistem kerangka otot adalah untuk mendukung dan melindungi bagian-bagian tubuh, mempertahankan postur tubuh, membangkitkan gerakan tubuh dan untuk menghasilkan panas serta mempertahankan suhu tubuh (Wickens dkk, 2004). Keluhan pada sistem 
muskuloskeletal disebabkan karena beban berlebihan/terlalu berat, gerakan tertentu yang berulang, sikap tubuh ketika duduk, berdiri dan melakukan aktivitas, dan tekanan kerja (Anonim, 2006). Aktivitas fisik yang dilakukan di tempat kerja dengan peralatan yang tidak ergonomis dapat menimbulkan cedera atau keluhan pada otot dan persendian.

Postur kerja atau sikap kerja yang baik adalah sikap kerja yang memungkinkan melaksanakan pekerjaan dengan efektif dan dengan usaha otot yang sedikit. Menurut Pheasant (2006) terdapat prinsip dasar dalam mengatasi sikap tubuh selama bekerja yaitu cegah inklinasi ke depan pada leher dan kepala, cegah inklinasi ke depan pada tubuh, cegah penggunaan anggota gerak bagian atas dalam keadaan terangkat, cegah pemutaran badan dalam sikap asimetris, persendian diharapkan dalam rentangan sepertiga dari gerakan maksimum dan jika menggunakan tenaga otot, diharapkan berada dalam posisi yang mengakibatkan kekuatan maksimal.

\section{METODE}

Penelitian dilaksanakan di PT Mandiri Jogja Internasional. Subjek penelitian adalah pekerja proses produksi kulit di divisi pemotongan yang terdiri atas 20 (dua puluh) orang pekerja laki-laki. Objek penelitian adalah postur kerja yang dinilai metode $R U L A$. Keluhan ekstremis atas dan faktor-faktor lain yang mempengaruhi UEWMSDs dicatat dengan Sympton Questionnaire, serta pengukuran antropometri tubuh. Kondisi lingkungan kerja dicatat.

\section{HASIL DAN PEMBAHASAN}

Lingkungan kerja di PT. Mandiri Jogja Internasional pada penelitian ini yang diambil adalah intensitas cahaya dan temperatur ruangan pada divisi pemotongan. Kondisi lingkungan yang diperoleh seperti pada Tabel 1.

Tabel 1

Data Kondisi Lingkungan Divisi Pemotongan

\begin{tabular}{clcc}
\hline No & Lingkungan Kerja & Kondisi & Keterangan \\
\hline 1 & Temperatur $\left({ }^{\circ} \mathrm{C}\right)$ & $29-30$ & \\
2 & Intensitas Cahaya (Lux) & 304 & $(0-1999)$ \\
\hline
\end{tabular}

Pegawai bagian pemotongan, bekerja dengan sikap kerja membungkuk. Kondisi postur kerja produksi kulit divisi pemotongan PT.Mandiri Jogja Internasional pada Gambar 1.

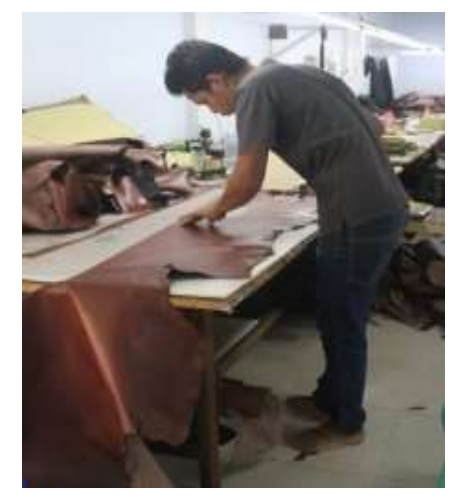

Gambar 1. Postur Kerja Divisi Pemotongan 
Data kondisi postur kerja produksi kulit divisi pemotongan PT. Mandiri Jogja Internasional sebelum penelitian. Pengukuran postur kerja menggunakan kamera digital untuk mengambil gambar postur kerja dari gambar yang diambil akan di ukur sudut postur kerja pada bagian sudut postur pekerja divisi pemotongan (Gambar 2).

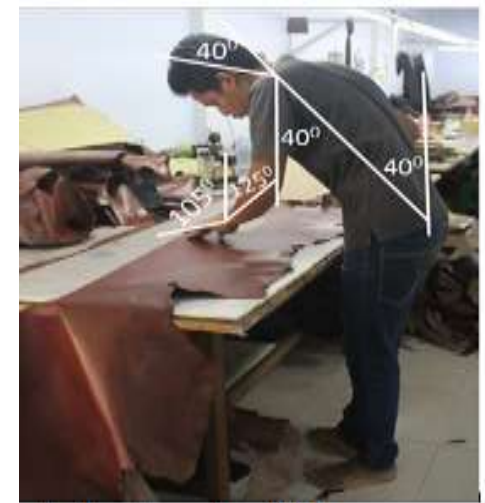

(a)

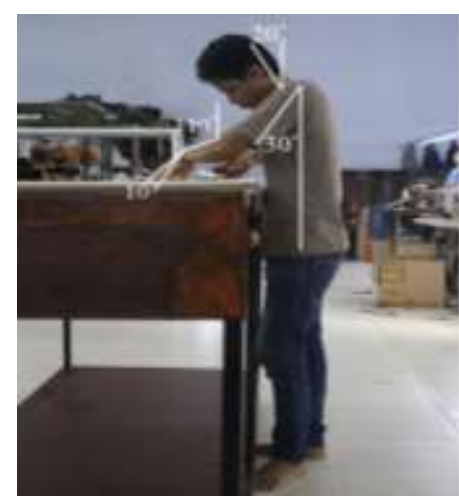

(b)

Gambar 2. Penilaian Postur Kerja (a) meja lama (b) meja sesuai antropometri

Hasil dari analisis umur pekerja didapatkan kriteria umur dengan jumlah $n=20$ (dua puluh) orang, rentangan umur pekerja antara 21 tahun sampai 41 tahun, dengan rata-rata 28 tahun (Tabel 2).

Tabel 2

Rekapitulasi Data Pekerja di Divisi Pemotongan

\begin{tabular}{clccc}
\hline No & Variabel & Rerata & Simpang Baku & Rentangan \\
\hline 1 & Umur (tahun) & 28 & 5,73 & $21-42$ \\
2 & Berat badan (kg) & 58 & 9,73 & $60-90$ \\
3 & Tinggi badan (cm) & 166 & 6,8 & $150-180$ \\
4 & Indeks Massa Tubuh (IMT) & 21,35 & 2,55 & $17,30-27,77$ \\
5 & Lama Bekerja (Bulan) & 67,6 & 31,06 & $24-120$ \\
\hline
\end{tabular}

Pada rentangan umur tersebut, merupakan usia produktif untuk bekerja. Menurut Tarwaka (2015), umur seseorang berbanding langsung dengan kapasitas fisik sampai batas tertentu dan mencapai puncak pada umur 25 tahun. Hal ini menunjukan bahwa umur pekerja dapat menunjang penelitian karena berada dalam rentangan umur dengan kemampuan fisiologi sesuai.

Hasil penelitian menunjukan kriteria berat badan antara $60 \mathrm{~kg}$ sampai $90 \mathrm{~kg}$, dengan rata-rata $58 \mathrm{~kg}$. Tinggi badan pekerja antara $150 \mathrm{~cm}$ sampai dengan $180 \mathrm{~cm}$, rata-rata dari tinggi pekerja adalah $166 \mathrm{~cm}$. Berdasarkan berat badan dan tinggi badan pekerja digunakan untuk menghitung Indeks Masa Tubuh (IMT) yang berguna untuk mengetahui keseimbangan energi yang masuk melalui asupan makanan dengan energi yang di keluarkan. Kelebihan dan kekurangan berat badan dapat mempengaruhi kinerja. IMT pekerja termasuk dalam kategori normal yaitu dengan rerata 21,35 dengan rentangan antara 17,30 - 27,77. Hal tersebut menunjukan status gizi pekerja divisi pemotongan PT. Mandiri Jogja Internasional baik dan dapat bekerja secara optimal.

Karakteristik subjek berdasarkan pendidikan dan status, dari 20 (dua puluh) orang pekerja divisi pemotongan, pendidikan mulai SD - SMA/SMK dan yang sudah nikah $60 \%$, 
yang belum nikah 40\%, karena sistem kerja divisi pemotongan PT. Mandiri Jogja Internasional tidak memerlukan keahlian khusus dapat dikerjakan pekerja (Tabel 3).

Tabel 3

Karakteristik Subjek berdasarkan Pendidikan dan Status

\begin{tabular}{|c|c|c|}
\hline No & Variabel & $\begin{array}{c}\text { Persentase } \\
(\%)\end{array}$ \\
\hline \multirow[t]{5}{*}{1} & Pendidikan & \\
\hline & SD & 5 \\
\hline & SMP & 20 \\
\hline & SMA & 65 \\
\hline & SMK & 10 \\
\hline \multirow[t]{3}{*}{2} & Status & \\
\hline & Nikah & 60 \\
\hline & Belum Nikah & 40 \\
\hline
\end{tabular}

Riwayat pekerjaan subjek penelitian, yang bekerja 1-4 tahun 25\%, yang bekerja 2-10 tahun $75 \%$, yang bekerja 8 jam perhari $100 \%$, yang tidak lembur $100 \%$, yang ada kerja sampingan 5\%, tidak ada kerja sampingan 95\%, yang ada petunjuk SOP ditempat kerja 95\%, tidak ada petunjuk SOP 5\%, yang ada pelatihan kerja 60\% dan yang tidak ada pelatihan kerja $40 \%$ (Tabel 4).

Tabel 4

Riwayat Pekerjaan Subjek Penelitian

\begin{tabular}{cllc}
\hline No & \multicolumn{2}{c}{ Variabel } & Persentase (\%) \\
\hline 1 & Lama Kerja (Tahun) & $1-4$ tahun & 25 \\
& & $5-10$ tahun & 75 \\
2 & Waktu Kerja (8 Jam) & & 100 \\
4 & Lembur & & 100 \\
5 & Kerja sampingan & Ya & 5 \\
& & Tidak & 95 \\
6 & \multirow{2}{*}{ SOP } & Ya & 95 \\
& & Tidak & 5 \\
7 & \multirow{2}{*}{ Pelatihan Kerja } & Ya & 60 \\
& & Tidak & 40 \\
\hline
\end{tabular}

Sebagian besar pekerja yang bekerja pada divisi pemotongan lebih dari 5 tahun artinya pengalaman bekerja cukup lama dan pekerja divisi pemotongan yang mendapatkan SOP dan pelatihan kerja sebagian besar mengikuti dilihat dari tingkat persentase di atas, akan tetapi dilihat dari lama kerja, masa kerja atau jam kerja, dan pekerjaan sampingan merupakan faktor yang meningkatkan terjadinya risiko $U E W M S D s$. Dari ketiga faktor tersebut, resiko terbesar disebabkan oleh pekerjaan sampingan karena selain melakukan pekerjaan dipabrik divisi pemotongan pekerja juga melakukan perkajaan sampingan dan jam istrahat kurang terpenuhi hal ini menyebabkan terjadinya keluhan UEWMSDs.

Karakteristik subjek tentang kebiasaan sehari-hari diluar jam kerja diperoleh yang berolah raga $50 \%$, tidak berolah raga $50 \%$, frekuensi yang berolah raga 50, frekuensi yang tidak berolah raga 50\%, lama olahraga 50\%, lama yang tidak olahraga 50\%, yang ada pekerjaan rumah 50\%, tidak ada pekerjaan rumah 50\%. Persentase pekerja yang kurang jam tidur 15\%, karena selain berkerja di PT. Mandiri Jogja Internasional pekerja juga melakukan pekerjaan rumah dan kerja sampingan dan pekerja jam tidur yang lebih adalah $25 \%$ karena tidak ada pekerjaan rumah dan kerja sampingan (Tabel 5). 
Hubungan karakteristik subjek tentang kebiasaan sehari-hari diluar jam kerja dengan penelitian adalah sebagian besar pekerja melakukan olahraga diluar jam kerja hal ini meningkatkan kebugaran fisik pekerja menjadi lebih baik disaat melakukan pekerjaan dan pekerja yang tidak melakukan kegiatan olahraga diluar jam kerja akan mudah mengalami risiko UEWMSDs.

Tabel 5

Kebiasaan Pekerja Sehari-Hari Diluar Jam Kerja

\begin{tabular}{cclc}
\hline No & \multicolumn{1}{c}{ Variabel } & & Persentase (\%) \\
\hline 1 & Olah Raga & Ya & 50 \\
& & Tidak & 50 \\
2 & Frekuensi Olahraga & Ya & 50 \\
& & Tidak & 50 \\
3 & Lama Olah Raga & Ya & 50 \\
& & Tidak & 50 \\
4 & Pekerjaan Rumah & Ya & 55 \\
& & Tidak & 45 \\
5 & \multirow{2}{*}{ Waktu Tidur (jam) } & Kurang & 15 \\
& & Normal & 60 \\
& & Lebih & 25 \\
\hline
\end{tabular}

Berdasarkan persentase jawaban Symtom Questionnaire diperoleh data UEWMSDs bahwa dari sisi keluhan sakit, Kuesioner A menunjukan bahwa sisi keluhan sakit tubuh bagian bahu dan lengan kanan adalah 50\%, dimana pertama kali merasakan sakit setelah pekerja 1-4 tahun yaitu 85\%, lama sakit yang dirasakan pekerja $<1$ jam sebesar $85 \%$, timbulnya rasa sakit yang dirasakan pekerja terus menerus adalah $75 \%$, penyebab rasa sakit tersebut timbul berhubungan dengan pekerjaan sebesar 95\%, yang dapat menambah rasa sakit yang dirasakan pekerja bila beraktivitas adalah $100 \%$, dan yang dapat mengurangi rasa sakit adalah istrahat sebesar $90 \%$ lainnya seperti pijit, minum jamu, obat sebesar $10 \%$.

Perbandingan data sebelum penelitian menggunakan metode RULA dimana total skor group A sebesar 4, total skor group B sebesar 5, dan skor gabungan 7 (tujuh) tingkat risiko 3 (tiga), termasuk dalam kategori sangat tinggi. Diperlukan investigasi dan perbaikan secepat mungkin terhadap kondisi postur kerja pada pekerjaan divisi pemotongan yang sedang dilakukan tersebut untuk mencegah tingkat risiko keluhan UEWMSDs. Berdasarkan perhitungan data dengan metode RULA, setelah perubahan, total skor group A sebesar 3 (tiga), total skor group B sebesar 2 (dua), dan skor gabungan 3 (tiga) tingkat risiko 1 (satu) kategori risiko rendah.

Data perhitungan persentil tinggi siku berdiri dan panjang jangkauan tangan pekerja divisi pemotongan PT. Mandiri Jogja Internasional, menggunakan rumus rerata seperti Rumus 1

$$
\mathrm{X}=\frac{\sum X}{N}
$$

dan rumus standar deviasi seperti Rumus 2.

$$
\sigma=\sqrt{\frac{(X j-X)^{2}}{N-1}}
$$

Hasil perhitungan diperoleh rerata tinggi siku pekerja divisi pemotongan adalah $106 \mathrm{~cm}$ dan panjang jangkauan tangan adalah 72,8 cm. Sementara persentil 99,5 untuk jangkauan tangan pekerja adalah 79. Panjang meja divisi pemotongan menggunakan ukuran panjang awal yaitu $244 \mathrm{~cm}$. 
Menurut Tarwaka (2015), penerapan antropometri adalah merupakan penggunaan data antropometri di dalam desain dan pemanfaatan. Perhitungan data fasilitas yang diambil dimensi tubuh pekerja divisi pemotongan adalah tinggi siku berdiri dan panjang jangkauan tangan pekerja. Data perhitungan persentil tinggi siku dalam centimeter yang diukur saat berdiri dan panjang jangkauan tangan. Didapatkan usulan tinggi meja kerja divisi pemotongan yang ergonomis adalah $103 \mathrm{~cm}$, dan usalan lebar meja kerja potong $79 \mathrm{~cm}$, data usulan ukuran meja kerja potong sesudah penelitian, untuk ukuran panjang meja menggunakan ukuran awal tidak diganti panjang meja kerja potong yaitu : $244 \mathrm{~cm}$, hal ini sesuai dengan penelitian Kristanto dan Saputra (2011), menyatakan perancangan meja dan kursi fasilitas kerja dapat berpengaruh terhadap hasil kerja hal ini didesain sesuai dengan pengukuran antropometri pekerja.

Dengan demikian usulan meja kerja yang sesuai dengan antropometeri pekerja divisi pemotongan seperti pada Gambar 3.

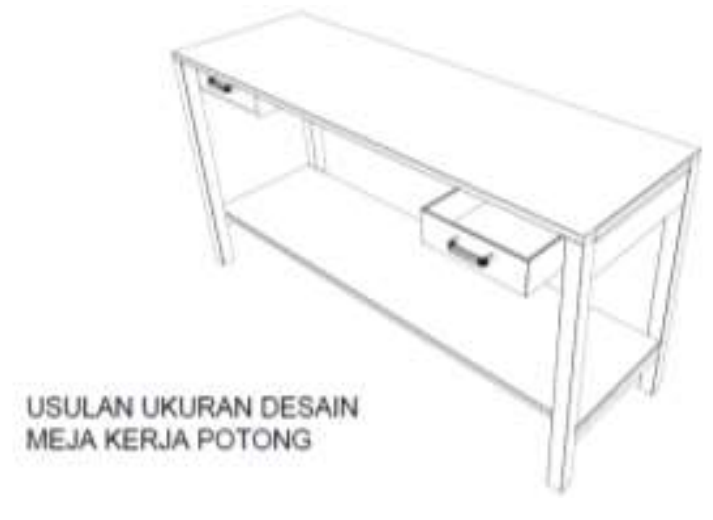

(a)

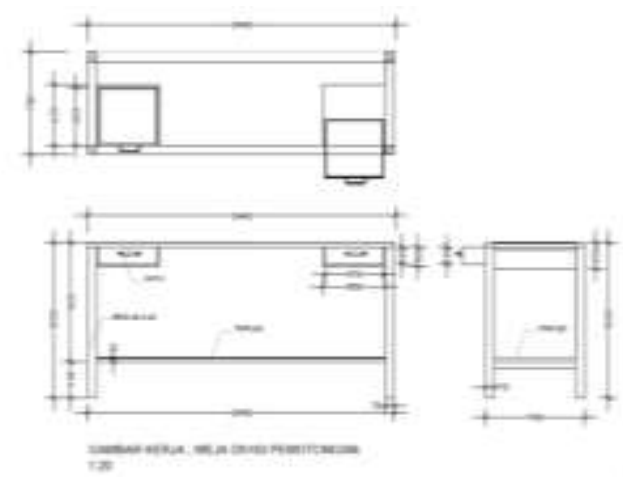

(b)

Gambar 3. Usulan Meja Potong a( desain) dan (b) ukuran

Penelitian ini ingin diketahui faktor-faktor risiko terhadap terjadi $U E W M S D$ s. Faktor tersebut adalah umur, status gizi, tingkat pendidikan, lama kerja, waktu kerja, kebiasaan olahraga, pekerjaan sampingan, waktu tidur, desain tempat kerja, pelatihan kerja, SOP, postur kerja pada waktu bekerja. Pada penelitian ini didapatkan bahwa faktor umur tidak ada hubungan dengan UEWMSDs, dikarenakan pekerja yang usia >40 tahun dijadikan ketua kelompok yang mengatur pembagian jam kerja sehingga paparan karena pekerjaan menjadi lebih sedikit.

Pada pabrik produksi kulit khusus divisi pemotongan keterampilan dalam proses pemotongan kulit lebih dipengaruhi oleh pengalaman yang berkaitan dengan masa kerja dan umur, dan juga yang mungkin menyebabkan dalam penelitian ini tidak didapatkan hubungan bermakna antara pendidikan dengan kelainan UEWMSDs. Ditambah lagi 95\% responden mengetahui adanya SOP dan yang mendapat pelatihan kerja $60 \%$.

Obesitas merupakan salah satu faktor risiko UEWMSDs. Pada penelitian ini tidak ada hubungan dengan antara status gizi dengan risiko $U E W M S D s$, kemungkinan karena jumlah responden IMT >23 yang berisiko obesitas hanya 5 responden. Sikap tubuh waktu bekerja dapat dicatat dan dinilai objektivitasnya dengan menggunakan observasi visual, antara lain dengan metode Skor Rapid Upper Limb Assessment (RULA). Buckle, dkk. (1994) menyatakan bahwa ketegangan otot leher, bahu, pundak atas dan otot punggung berhubungan dengan posisi lingkungan tempat kerja yang buruk. Dalam penelitian ini didapatkan dimana skor group A sebesar 4 (empat), total skor group B sebesar 5 (lima) dan skor gabungan sebesar 7 (tujuh), hal ini menunjukan pekerja divisi pemotongan mengalami tingkat risiko 
UEWMSDs. Dengan demikian diperlukan investigasi dan perbaikan secepat mungkin terhadap postur kerja pada pekerja divisi pemotongan untuk mencegah terjadi tingkat risiko keluhan $U E W M S D s$, penelitian ini menunjukan hubungan bermakna antara postur kerja pada waktu bekerja dengan risiko UEWMSDs.

Berdasarkan nilai skor RULA yang diperoleh, dengan melihat daftar tindakan dapat diketahui tingkat intervensi atau upaya untuk meningkatkan kesehatan, yang dibutuhkan untuk mengurangi risiko trauma yang disebabkan beban fisik yang dialami pekerja. Dalam penelitian metode RULA dipilih karena lebih lengkap untuk menilai ekstremitas atas yang curiga terjadi UEWMSDs serta mudah dilaksanakan, waktu singkat biaya murah dan fleksibel, sehingga $R U L A$ bisa dijadikan alat skrining di temat kerja.

\section{SIMPULAN}

Dapat disimpulkan bahwa postur kerja terhadap tingkat risiko UEWMSDs dalam penelitian ini yang diukur dengan metode RULA adalah sebesar 7 (tujuh). Hal ini menunjukkan pekerja divisi pemotongan mengalami tingkat risiko keluhan UEWMSDs. Dengan demikian diperlukan investigasi dan perbaikan segera terhadap postur kerja pada pekerja untuk mencegah tingkat risiko keluhan UEWMSDs. Berdasarkan hasil perbaikan didapatkan total skor gabungan 3 (tiga) tingkat risiko 1 (satu) yang berarti kategori risiko rendah. Tidak ada masalah dengan postur tubuh pekerja pada perkerja divisi pemotongan PT. Mandiri Jogja Internasional. Penelitian ini menunjukan ada faktor-faktor postur kerja yang berhubungan dengan tingkat risiko keluhan UEWMSDs antara lain, lama kerja, masa kerja atau jam kerja, dan pekerjaan sampingan merupakan faktor yang meningkatkan risiko UEWMSDs. Dari ketiga faktor tersebut, resiko terbesar disebabkan oleh pekerjaan sampingan karena selain melakukan pekerjaan di pabrik divisi pemotongan, pekerja juga melakukan perkajaan sampingan dan jam istirahat berkurang sehingga menyebabkan terjadi keluhan UEWMSDs.

\section{DAFTAR PUSTAKA}

Anonim. 2006. Daihatsu Fokus Produksi Mobil Compact. Harian Republika. Rabu, 14 Juni, halaman 14, kolom 9-10.

Kristanto, A. dan Saputrra, D.A. 2011. Jurnal Ilmiah Teknik Industri, Vol. 101(2).

Buckle P. 1994. Ergonomic Stressor Related to Neurogical Disorders of the Upper Limb. In : Bleecker, Malgit L. MD,PhD. Hansen JA. MD, MPH. Editors. Occupational Neurology and Clinical Neurotoxicology. Baltimore: William \& Wilkins. p.253-283.

Corlett, E.N. 1992. Static Muscle Loading and Evaluation of Posture. In: Wilson, J.R. \& Corlett, E.N. Editors. Evaluation of Human Work a Practisel Ergonomics Methodology. London: Taylor \& Francis. p.542-570.

Manuaba, A. 1998. Ergonomi Menopang Efisiensi dan Keselamatan Kerja, Bunga Rampai Ergonomi. Denpasar: Program Studi Ergonomi-Fisiologi Kerja Universitas Udayana.

Dzikrillah, N. dan Yuliani, E.N.S. 2015. Jurnal Analisis Postur Kerja Menggunakan Metode Rapi Upper Limb Assessment (RULA) Studi Kasus PT. TJ FORGE INDONESIA.

Pheasants, S. 2006. Body Space, Anthropometry, Ergonomics And The Design Of Work, London: Taylor \& Francis.

Tarwaka, Solichul H., Bakri, A. dan Sudiajeng, L. 2004. Ergonomi Untuk Kesehatan dan Keselamatan Kerja dan Produktivitas. Surakarta: UNIBA Press.

Hartono, W. 2004. Jurnal Hubungan Antara Sikap Dan Posisi Anggota Tubuh Dengan UEWMSDs Pada Kerajinan Rotan di Perusahaan X Cirebon. 